Agnieszka Polus

\title{
Glosa aprobująca do wyroku Sądu Najwyższego \\ z 21.10.2016 r., V CSK 26/16
}

Glosowane orzeczenie dotyczy pytania, czy postępowanie sądowe w wyniku którego doszło do uchylenia decyzji (o którym mowa w art. 287 pkt 1 ustawy z 30.8.2002 r. Prawo postępowaniu przed sądami administracyjnymi), może zostać uznane za „właściwe postępowanie" zmierzające do stwierdzenia niezgodności z prawem decyzji administracyjnej (art. $417^{1} \S 2$ Kodeksu cywilnego). Sąd Najwyższy stanął na stanowisku, że art. 287 pkt 1 ustawy Prawo postępowaniu przed sądami administracyjnymi może być rozumiany także w ten sposób, że przewiduje dodatkową przesłankę odpowiedzialności odszkodowawczej za szkodę wyrządzoną wykonywaniem władzy publicznej, która zachodzi wtedy, gdy w postępowaniu administracyjnym prowadzonym w celu wykonania uchylającego decyzję wyroku sądu administracyjnego dojdzie do umorzenia postępowania. Na poparcie tezy Sądu Najwyższego warto przytoczyć dwa argumenty: po pierwsze, art. 287 pkt 1 ustawy Prawo postępowaniu przed sądami administracyjnymi nie zawiera pełnego unormowania odpowiedzialności odszkodowawczej za szkody spowodowane decyzjami administracyjnymi, które następnie zostały uchylone przez sąd administracyjny; po drugie, przepis ten nie wskazuje podmiotów właściwych do orzekania w sprawach o odszkodowanie, nie określa też zakresu odpowiedzialności, ani zasad wymiaru odszkodowania.

\section{Teza wyroku:}

„1. Postępowanie sądowoadministracyjne, obok nadzwyczajnych postępowań administracyjnych, musi być uznane za ,właściwe postępowanie” w rozumieniu art. $417^{1} \S 2$ k.c., którego przeprowadzenie prowadzi do powstania prejudykatu dla odpowiedzialności odszkodowawczej za szkodę spowodowaną wydaniem ostatecznej decyzji administracyjnej.

2. Przepis art. 287 pkt 1 ustawy z 30 sierpnia 2002 r. Prawo postępowaniu przed sądami administracyjnymi może być rozumiany i w ten sposób, że przewiduje dodatkową przesłankę odpowiedzialności odszkodowawczej za szkodę wyrządzoną wykonywaniem władzy publicznej, która zachodzi wtedy, gdy w postępowaniu administracyjnym prowadzonym w celu wykonania uchylającego decyzję wyroku sądu administracyjnego dojdzie do umorzenia postępowania. Przyjęcie, że także to zdarzenie może uzasadniać 
odpowiedzialność odszkodowawczą za szkodę wyrządzoną przez wykonywanie władzy publicznej nie eliminuje z zakresu zdarzeń rodzących tego rodzaju odpowiedzialność samego wydania ostatecznej decyzji, obarczonej jednak wadą, która uzasadniała jej uchylenie (art. $145 \S 1$ pkt 1 ustawy) względnie stwierdzenie nieważności (art. $145 \S 1$ pkt 2 ustawy) przez sąd, niezależnie od tego, czy po wydaniu przez sąd wyroku uchylającego decyzję doszło do umorzenia postępowania administracyjnego w sprawie." 1

2. Glosowane orzeczenie dotyczy problemu odpowiedzialności odszkodowawczej Skarbu Państwa za wydanie niezgodnej z prawem ostatecznej decyzji administracyjnej. Dają się tutaj dostrzec dwie kwestie. Po pierwsze czy postępowanie sądowe w wyniku którego doszło do uchylenia decyzji (o którym mowa w art. 287 pkt 1 ustawy z 30.8.2002 r. Prawo postępowaniu przed sądamiadministracyjnymi ${ }^{2}$ ), może zostać uznane za „właściwe postępowanie” zmierzające do stwierdzenia niezgodności z prawem decyzji administracyjnej (art. $417^{1} \S 2$ Kodeksu cywilnego ${ }^{3}$ ). Po drugie, pojawia się kwestia pojęć: „niezgodność z prawem” oraz „decyzja ostateczna”. Stanowisko zajęte przez Sąd Najwyższy, z uwagi na doniosłe znaczenie dla praktyki obrotu zasługuje na kilka słów komentarza w celu potwierdzenia jego słuszności.

3. Powód - K. Spółka z ograniczoną odpowiedzialnością spółka komandytowa wniósł o zasądzenie od Gminy Miasta G. odszkodowania za szkodę spowodowaną wydaniem wadliwej decyzji o warunkach zabudowy oraz o zatwierdzeniu projektu budowlanego i udzieleniu pozwolenia na budowę. Gmina Miasta G. wniosła o oddalenie powództwa. Na wniosek powoda do udziału w sprawie w charakterze pozwanego został wezwany Skarb Państwa - reprezentowany przez Prezydenta Miasta G., który także wniósł o oddalenie powództwa. Postanowieniem z 7.10.2013 r. Sąd ustalił statio fisci Skarbu Państwa W niniejszej sprawie i przyjął, że obok Prezydenta Miasta G. jest nim także Wojewoda. Wyrokiem z 12.12.2013 r. Sąd Okręgowy w G. oddalił powództwo. Sąd ten ustalił, że 29.11.2004 r. Prezydent Miasta G. na wniosek spółki z ograniczoną odpowiedzialnością „P.” wydał decyzję o warunkach zabudowy działek przy ul. U. w G. Decyzją z 22.04.2005 r. Samorządowe Kolegium Odwoławcze w G. po rozpoznaniu odwołania od decyzji Prezydenta Miasta G. z 29.11.2004 r., utrzymało tę decyzję w mocy. Spółka „P.” 1.2.2007 r. wystąpiła

\footnotetext{
${ }^{1}$ Wyrok SN z 21.10.2016 r., V CSK 26/16, Legalis nr 1537676.

${ }^{2}$ Ustawa z 30.8.2002 r. Prawo o postępowaniu przed sądami administracyjnymi (t.j. Dz.U. z 2016 r. poz. 718 ze zm.), dalej jako PostAdmU.

${ }^{3}$ Ustawa z 23.4.1964 r. Kodeks cywilny (t.j. Dz.U. z 2017 r. poz. 459), dalej jako k.c.
} 
o wydanie pozwolenia na budowę w G. przy ul. U. Decyzją z 3.4.2007 r. Prezydent Miasta G. zatwierdził projekt budowlany oraz udzielił spółce „P.” pozwolenia na budowę. Wojewoda decyzją z 2.7.2007 r., wydaną na skutek odwołań od decyzji z 3.4.2007 r., utrzymał tę decyzję w mocy, a postanowieniem z 26.3.2008 r. odmówił wstrzymania jej wykonania. Wyrokiem z 9.4.2008 r., Wojewódzki Sąd Administracyjny w G. po rozpoznaniu skargi na decyzję Wojewody z 2.7.2007 r. uchylił tę decyzję oraz decyzję Prezydenta Miasta G. z 3.4.2007 r. i orzekł, że decyzje te nie mogą być wykonywane. Naczelny Sąd Administracyjny wyrokiem z 1.9.2009 r., oddalił skargę kasacyjną powoda. Decyzją z 26.10.2010 r. Prezydent Miasta G. odmówił zatwierdzenia projektu budowlanego i udzielenia spółce „P.” pozwolenia na budowę budynku mieszkalnego wielorodzinnego przy ul. U. Powód 21.7.2011 r. wystąpił o wydanie decyzji o warunkach zabudowy dla działek przy ul. U. w G. Decyzją z 28.12.2011 r. Prezydent Miasta G. ustalił warunki zabudowy dla działek przy ul. U. w G. Decyzją z 6.11.2012 r. Samorządowe Kolegium Odwoławcze w G. uchyliło decyzję Prezydenta Miasta G. z 28.12.2011 r. i sprawę przekazało do ponownego rozpatrzenia. Decyzją z 8.1.2013 r. Prezydent Miasta G. umorzył postępowanie w sprawie ustalenia warunków zabudowy.

4. W glosowanym wyroku Sąd Najwyższy podkreślił, że ustawodawca w art. $417^{1} \S 2$ k.c. nie wyjaśnił, jak należałoby rozumieć pojęcie „niezgodność z prawem” decyzji rodzącej odpowiedzialność odszkodowawczą. Wskazał jedynie na skorelowanie tego pojęcia z „właściwym postępowaniem”, a zatem takim, w którym może dojść do stwierdzenia, że weryfikowana decyzja jest niezgodna z prawem.

Podejmując próbę ustosunkowania się do powyższej kwestii, warto wskazać, że ustawodawca oparł odpowiedzialność za wydanie ostatecznej decyzji na następujących przesłankach: niezgodności z prawem ostatecznej decyzji, szkody powstałej na skutek wydania decyzji, związek przyczynowy oraz stwierdzenia we właściwym postępowaniu niezgodności z prawem ${ }^{4}$. Przesłanki szkody oraz związku przyczynowego są jasne. Wątpliwości interpretacyjne budzą natomiast przesłanki niezgodności z prawem ostatecznej decyzji oraz definicja ,właściwego postępowania”, o którym mowa w art. $417^{1} \S 2$ k.c.

Odnosząc się do kwestii niezgodności z prawem ostatecznej decyzji należy sięgnąć do regulacji art. $16 \S 1$ k.p.a. Zgodnie z tym unormowaniem, przez decyzję ostateczną należy rozumieć decyzję, od której nie służy odwołanie w administracyjnym toku instancji lub

\footnotetext{
${ }^{4}$ Z. Banaszczyk, [w:]Kodeks cywilny. Tom I. Komentarz, red. K. Pietrzykowski, Warszawa 2015, s. 1390.
} 
wniosek o ponowne rozpatrzenie sprawy. Decyzje takie mogą być zaskarżane do sądu administracyjnego z powodu ich niezgodności z prawem, na zasadach i w trybie określonym w odrębnych ustawach (16 $§ 2$ k.p.a.).

W tym zakresie należy ponadto zaznaczyć, że w doktrynie przyjmuje się powszechnie, że decyzja administracyjna jest zgodna z prawem, jeżeli została wydana zgodnie z przepisami prawa materialnego i procesowego. Ich naruszenie pociąga za sobą niezgodność z prawem decyzji administracyjnej. ${ }^{5} \mathrm{~W}$ orzecznictwie przyjmuje się, że każda decyzja, która zostanie zmieniona lub uchylona $\mathrm{w}$ drodze postępowania instancyjnego lub postępowania przed sądem administracyjnym stanowi podstawę odpowiedzialności odszkodowawczej za wykonywanie władzy publicznej ${ }^{6}$. Warto wskazać, że ustawodawca powiązał odpowiedzialność odszkodowawczą Skarbu Państwa za decyzje administracyjne z ostatecznymi decyzjami, a więc decyzjami, od których nie przysługują środki zaskarżania w administracyjnym toku instancji.

W świetle poczynionych uwag pojawia się pytanie, czy postępowanie sądowe, w wyniku którego doszło do uchylenia decyzji administracyjnej (art. 287 pkt 1 PostAdmU) może być uznane za „właściwe postępowanie” zmierzające do stwierdzenia niezgodności z prawem ostatecznej decyzji w rozumieniu art. $417^{1} \S 2$ k.c. Innymi słowy, czy postępowanie przewidziane w art. 287 pkt 1 PostAdmU, może stanowić prejudykat dla postępowania o którym mowa w art. $417^{1} \S 2$ k.c.

W dotychczasowym orzecznictwie Sądu Najwyższego w zakresie rozważanej kwestii ugruntowały się dwa stanowiska. Zgodnie $\mathrm{z}$ pierwszym intencją ustawodawcy przy wprowadzaniu regulacji art. 287 pkt 1 PostAdmU było wyłączenie z katalogu zdarzeń powodujących odpowiedzialność odszkodowawczą sytuacji, w których organ administracji publicznej wydał decyzję wadliwą $\mathrm{w}$ stopniu uzasadniającym jej uchylenie przez sąd (art. $145 \S 1$ pkt 1PostAdmU), a postępowanie administracyjne prowadzone w celu wykonania wyroku sądu administracyjnego nie zakończyło się umorzeniem, lecz wydaniem decyzji merytorycznej. Drugie stanowisko (do którego przychylił się także Sąd Najwyższy w głosowanym orzeczeniu) zakłada że art. 287 pkt 1 PostAdmU może być rozumiany także $\mathrm{w}$ ten sposób, że przewiduje dodatkową przesłankę odpowiedzialności odszkodowawczej za szkodę wyrządzoną wykonywaniem władzy publicznej. Zachodzi ona wówczas, gdy w postępowaniu administracyjnym prowadzonym w celu wykonania uchylającego decyzję wyroku sądu administracyjnego dojdzie do umorzenia postępowania.

\footnotetext{
${ }_{6}^{5}$ B. Adamiak, Komentarz do art. 16, Kodeks postępowania administracyjnego. Komentarz, Legalis 2016, Nb 6.

${ }^{6}$ Zob. wyrok SA z 17.5.2013 r., I ACa 1042/12, Legalis nr 1048911.
} 
5. Ustosunkowując się do zajętego przez Sąd Najwyższy stanowiska, warto odnieść się do kilku kwestii. Po pierwsze czy regulacja zawarta w art. 287 pkt 1 PostAdmU może stanowić samodzielną podstawę odpowiedzialności odszkodowawczej w sytuacji gdy sąd uchylił zaskarżoną decyzję, a organ administracji publicznej rozpatrujący sprawę ponownie umorzył postępowanie. W tym zakresie warto odnieść się do dorobku orzecznictwa, które wskazuje, że art. 287 pkt. 1 PostAdmU nie zawiera pełnego unormowania odpowiedzialności odszkodowawczej za szkody spowodowane decyzjami administracyjnymi, które następnie zostały uchylone przez sąd administracyjny ${ }^{7}$. Należy też podzielić trafne stanowisko prezentowane przez doktrynę, której zdaniem art. 287 pkt 1 PostAdmU wskazuje jedynie adresata roszczenia oraz doprecyzowuje podstawy odpowiedzialności odszkodowawczej ${ }^{8}$. Należy przy tym zauważyć, że regulacja zawarta w art. 287 pkt 1 PostAdmU nie stanowi samodzielnej podstawy roszczenia odszkodowawczego strony poszkodowanej zaskarżoną decyzją, która została następnie uchylona przez sąd, a organ rozpatrujący sprawę ponownie umorzył postępowanie.

Za stanowiskiem zajętym przez Sąd Najwyższy w glosowanym orzeczeniu przemawia również fakt, że komentowany przepis nie określa podmiotów właściwych do orzekania w sprawach o odszkodowanie, nie określa też zakresu odpowiedzialności, ani zasad wymiaru odszkodowania za wydanie niezgodnej z prawem ostatecznej decyzji administracyjnej. Trudno więc przyjąć, by stanowił samodzielną podstawę odpowiedzialności odszkodowawczej. Podstawa odpowiedzialności odszkodowawczej za wydanie niezgodnej z prawem ostatecznej decyzji administracyjnej została bowiem określona w art. $417^{1} \S 2$ k.c. ${ }^{9}$.

Podzielając tezę, że art. 287 pkt 1 PostAdmU nie stanowi samodzielnej podstawy odpowiedzialności, należy rozważyć czy postępowanie w nim określone może stanowić dodatkową przesłankę odpowiedzialność Skarbu Państwa za wydanie niezgodnej z prawem decyzji administracyjnej o której mowa w art. $417^{1} \S 2$ k.c. Innymi słowy, wymaga ustalenia, czy postępowanie, o którym mowa w art. 287 pkt 1 PostAdmU może zostać uznane za „właściwe postępowanie” w rozumieniu art. $417^{1} \S 2$ k.c.

Podejmując próbę rozważenia przedstawionego zagadnienia należy odnieść się do pojęcia „właściwego postępowania” ujętego w art. $417^{1} \S \quad 2$ k.c.

\footnotetext{
${ }^{7}$ Wyrok WSA w Warszawie z 5.2.2008 r., VII SA/Wa 1946/07, Legalis nr 260580.

${ }^{8}$ E. Bagińska, System prawa administracyjnego. Tom 12. Odpowiedzialność odszkodowawcza $w$ administracji, Warszawa 2010 r., s. 340-341.

${ }^{9}$ Wyrok SA w Warszawie z 13.6.2013 r. I ACa 44/13, Legalis nr 741382. Zob. M. Safjan, K. Matuszyk, Odpowiedzialność odszkodowawcza władzy publicznej, Warszawa 2009, s. 116.
} 
Jak podkreśla się w doktrynie należy przez nie rozumieć procedurę, którą ustawodawca przewidział jako środek kontroli zgodności z prawem decyzji ${ }^{10}$. Oznacza to, że niezbędnego prejudykatu należy szukać w przepisach materialnego prawa administracyjnego, które przewidują tryb kontroli decyzji administracyjnych ${ }^{11}$. Zgodnie z regulacją zawartą w przepisach materialnego prawa administracyjnego, do stwierdzenia niezgodności z prawem ostatecznej decyzji może dojść, po pierwsze na zasadach określonych w przepisach kodeksu postępowania administracyjnego, poprzez stwierdzenie nieważności decyzji (art. 156 k.p.a.) lub uchylenia w wyniku wznowienia postępowania (art. 145 i n. k.p.a.). Po drugie, na drodze sądowej w trybie przewidzianym $\mathrm{w}$ art. 145 PostAdmU poprzez m.in. uchylenie decyzji w całości lub w części, stwierdzenie nieważności decyzji lub stwierdzenie, że decyzja została wydana $\mathrm{z}$ naruszeniem prawa.

Odnosząc się do kwestii wzajemnej korelacji art. $417^{1} \S^{2} \quad 2$ k.c. i art. 287 pkt 1 PostAdmU, warto wskazać na słuszny pogląd zaprezentowany w doktrynie, w myśl którego orzeczenie sądu administracyjnego, o którym mowa w art. 287 pkt 1 PostAdmU, ma charakter prejudykatu, a tym samym spełnia funkcję „właściwego postępowania" w rozumieniu art. $417 \S 2$ k.c. ${ }^{12}$. Podkreślić przy tym należy, że treść art. 287 PostAdmU potwierdza zastosowanie ogólnej reguły odpowiedzialności ukształtowanej w kodeksie cywilnym, a jego regulacja sprowadza się do oznaczenia organu, który jest adresatem roszczenia ${ }^{13}$.

6. W świetle wskazanych rozważań, można przyjąć, że postępowanie, o którym mowa $\mathrm{W}$ art. 287 pkt 1 PostAdmU, stanowi szczególną przesłankę odpowiedzialności Skarbu Państwa za wydanie niezgodnej z prawem ostatecznej decyzji administracyjnej. Oznacza to, że w sytuacji, w której sąd rozpatrujący sprawę w wyniku odwołania uchylił zaskarżoną decyzję, a organ administracji publicznej umorzył postępowanie, strona może dochodzić odszkodowania w postępowaniu przed sądem powszechnym na podstawie przepisów art. $417-417^{2}$ k.c. ${ }^{14}$

Stanowisko Sądu Najwyższego zajęte w glosowanym wyroku można wzmocnić dodatkową konstatacją, że skoro ustawodawca w art. $417^{1} \S 2$ k.c. nie określił expressis verbis

\footnotetext{
${ }^{10}$ Z. Banaszczyk, Kodeks cywilny... op.cit, s.1392.

${ }^{11}$ Ibidem, s. 1392.

${ }^{12}$ Z. Banaszczyk, Odpowiedzialność za szkody wyrządzone przy wykonywaniu władzy publicznej, Warszawa 2012, s. 241-242.

${ }^{13}$ M Safjan, Odpowiedzialność odszkodowawcza władzy publicznej po 1 września 2004 r. Warszawa 2004, s. 72-73.

${ }^{14}$ A. Kabat, [w:] Prawo o postepowaniu przed sądami administracyjnymi. Komentarz, Warszawa 2009, s. 776.
} 
jakie postępowanie jest właściwe do stwierdzenia niezgodności z prawem ostatecznych decyzji, to funkcję taką mogłoby pełnić, co do zasady, każde postępowanie, w którym może dojść do weryfikacji decyzji. Jak wiadomo, system weryfikacji decyzji administracyjnych opiera się na kontroli decyzji w drodze administracyjnej oraz w postępowaniu sądowym ${ }^{15}$. W tym świetle należy przyjąć, że „właściwym postępowaniem”, w którym dochodzi do stwierdzenia niezgodności z prawem ostatecznych decyzji, może być ekstraordynaryjne postępowanie toczące się przed organami administracji publicznej, jak i sądami administracyjnymi ${ }^{16}$.

Konkludując, uprawniony może wystąpić z roszczeniem odszkodowawczym za wydanie niezgodnej z prawem ostatecznej decyzji, o którym mowa w art. $417^{1} \S 2$ k.c. Nie musi on przed wystąpieniem z powództwem o odszkodowanie uzyskać prejudykatu stwierdzającego niezgodność $\mathrm{z}$ prawem zaskarżonej decyzji. Wymóg „właściwego postępowania”, o którym mowa w art. $417^{1} \S 2$ k.c., spełnia bowiem orzeczenie sądu administracyjnego, uregulowane w art. 287 pkt 1 PostAdmU, stanowiąc konieczny i wyłączny prejudykat dla roszczenia odszkodowawczego za wydanie niezgodnej z prawem ostatecznej decyzji ${ }^{17}$. Stanowisko Sądu Najwyższego wyrażone w głosowanym orzeczeniu zasługuje na pełną aprobatę.

\footnotetext{
${ }^{15}$ B. Adamiak, Wadliwość decyzji administracyjnych, Wrocław 1986, s. 117.

${ }^{16}$ P. Sobolewski, op.cit., s. 13. Zob. też Wyrok SA w Warszawie z 17.5.2013 r., I ACa 1042/12, Legalis nr 1048911.

${ }^{17}$ T. Woś, Prawo o postępowaniu przed sądami administracyjnymi. Komentarz, Warszawa 2012, s.1205.
} 
Summary. The judgment refers to the issue, whether the court proceedings resulting in the abrogation of the administrative decision (referred to in Article 287, point 1 of the Administravive Proceeding Act - hereinafter refered as APA) may be regarded as a "proper proceeding", which aim to determine the unlawfulness of such aadministrative decision (article $4171 \S 2$ of Polish Civil Code - hereinafter refered as PCC). In the judgment the Polish Supreme Court held that article 287 item 1 of the APA may also be construed in such manner, that it provides an additional premise for the liability for damages caused by the exercise of public authority, which occurs, when in the administrative proceeding, conducted in order to execute the administrative court's judgment repealing the administrative decision, the above-mentioned administrative proceeding would be discontinued. The thesis of the Supreme Court may be supported by the following argumentation. First, article 287 item 1 of the APA does not contain the full regulation of the liability for damages caused by administrative decisions, which were subsequently abolished by the administrative court. Second, this provision does not specify entites entitled to adjudicate on damages, nor set out the scope of liability or the principles of compensation.

\section{Agnieszka Polus}

Absolwentka Wydziału Prawa i Administracji Uniwersytetu Mikołaja Kopernika w Toruniu. 